North American Journal of Fisheries Management 21:34-45, 2001

(C) Copyright by the American Fisheries Society 2001

\title{
Reservoir Striped Bass Movements and Site Fidelity in Relation to Seasonal Patterns in Habitat Quality
}

\author{
JAMES R. JACKSON*1 \\ Department of Zoology, North Carolina State University, \\ Campus Box 7617, Raleigh, North Carolina 27695-7617, USA \\ Joseph E. Hightower \\ U.S. Geological Survey, Biological Resources Division, \\ North Carolina Cooperative Fish and Wildlife Research Unit, \\ Department of Zoology, North Carolina State University, \\ Raleigh, North Carolina 27695-7617, USA
}

\begin{abstract}
Adult striped bass Morone saxatilis perform best when water temperatures are below $26^{\circ} \mathrm{C}$ and dissolved oxygen levels are above $2 \mathrm{mg} / \mathrm{L}$ and will begin to exhibit stress responses at higher temperatures or lower oxygen levels. In southern U.S. reservoirs, summer conditions may result in a reduction of suitable habitat for adult striped bass and therefore influence population dynamics and distribution. We tracked 51 adult striped bass that had been implanted with individually coded sonic transmitters for 2 years in Lake Gaston, Virginia-North Carolina, to determine the impact of habitat availability on seasonal trends in movement and distribution. Monthly movement rates of individual fish averaged 7,340 $\mathrm{m}(\mathrm{SE}=544 \mathrm{~m})$ over the course of the study, and no significant differences in movement rates were detected among seasons or between sexes. Striped bass were relocated throughout the reservoir in all seasons despite evidence of spatial variability in the availability of suitable habitat during the summer months. Individual striped bass tended to occupy specific reservoir areas in all seasons and years of the study, with the exception of spring spawning runs. Home ranges of individual fish were not clearly related to the availability of summer habitat refuges but tended to be located in large, downlake basins or near the tailrace of an upstream dam. Fidelity of striped bass to limited areas within the reservoir suggests that spatially explicit management strategies are appropriate for reservoir populations of striped bass.
\end{abstract}

Striped bass Morone saxatilis have been stocked into reservoirs throughout the United States, most often with the dual objectives of establishing recreational fisheries and controlling clupeid populations (Axon and Whitehurst 1985). Striped bass stockings have resulted in the development of successful fisheries in many reservoirs (Stevens 1958; Nash et al. 1988), but reservoir populations of striped bass are frequently characterized by slow growth and high rates of natural mortality, particularly in southern U.S. systems (Matthews 1985; Kohler et al. 1986). Although the success of striped bass stockings in reservoirs depends in large part on the availability of a suitable forage base, environmental conditions have also been shown to influence adult striped bass population dynamics (Bailey 1975). As a result, assessment of the suitability of specific systems for striped bass intro-

\footnotetext{
* Corresponding author: jrj26@ cornell.edu

${ }^{1}$ Present address: Cornell Biological Field Station, 900 Shackleton Point Road, Bridgeport, New York 13030, USA.

Received February 17, 2000; accepted June 26, 2000
}

duction must incorporate information not only on potential predator-prey interactions but also on habitat availability and its potential impacts on striped bass behavior.

Coutant (1985) proposed a hypothesis of ontogenetic thermal-niche partitioning in striped bass that has led to productive research in the area of environmental impacts on reservoir striped bass populations. Subadult striped bass up to about age 2 can survive and grow at water temperatures up to $30^{\circ} \mathrm{C}$, but older fish exhibit stress responses as water temperatures climb above $26-27^{\circ} \mathrm{C}$ (Coutant 1985). Additionally, striped bass require at least 2-3 mg dissolved oxygen/L (Coutant 1985). In southern reservoirs, therefore, stocked juveniles may thrive at typical summer water temperatures, but adult population dynamics may be controlled by the availability of cool water with adequate dissolved oxygen. Recent studies have indicated that adult striped bass will cease feeding as water temperatures approach $27^{\circ} \mathrm{C}$ and that mortality becomes likely if temperatures remain above $28^{\circ} \mathrm{C}$ for extended periods (Zale et al. 1990). Consistent with these findings, Matthews (1985) reported that summer kills of striped bass were widespread in 
southern reservoirs where the species has been established and that a disproportionate number of large fish died. In many southern reservoirs during the summer months, habitat with suitable temperature and adequate oxygen may become restricted both horizontally and vertically to limited refuges, or it may not be available at all.

Telemetry studies have shown that the limited availability of suitable summer habitat can concentrate striped bass within restricted areas of a reservoir, typically either in the deeper waters near the dam or in the tailwaters of upstream reservoirs, throughout much of the growing season. Combs and Peltz (1982), working in an Oklahoma reservoir, and Farquhar and Gutreuter (1989), working in Texas, reported that during summer striped bass were concentrated in the deeper waters of lower reservoir areas where a layer of cooler water with adequate oxygen persisted after summer stratification. Conversely, Cheek et al. (1985) found that during summer striped bass in a Tennessee reservoir were concentrated in the upper tributary arms where groundwater inflows and hypolimnetic discharges from upstream dams provided inputs of cooler water. Similar summer use of coolwater discharges from upstream dams was documented by Moss (1985) in Alabama reservoirs. The importance of habitat in determining adult striped bass distributions has been further supported by Wilkerson and Fisher (1997), who reported that striped bass in an Oklahoma reservoir exhibited strong site fidelity to areas that offered preferred habitat throughout the year.

We conducted a 2-year telemetry study of 51 adult striped bass in Lake Gaston, North Carolina-Virginia, to assess seasonal movements, distribution, and mortality rates. Our study resulted in detailed seasonal-movement and distribution data on individually tracked fish over 2 years; we are not aware of other published studies of comparable size or duration. In this paper, we report seasonal patterns in fish movement and distribution and relate summer behavior to the availability of suitable habitat. In addition, we assess the possibility of fidelity on the part of individual fish to specific areas of the reservoir. We also compare the relative weights of striped bass in Lake Gaston with those reported for other inland populations. Finally, we offer observations on the importance of capture method and release site in telemetry studies involving striped bass.

\section{Study Site}

Lake Gaston is an 8,215-ha impoundment of the Roanoke River located on the Virginia-North Car- olina border (Figure 1). The lake is the second in a chain of three reservoirs on the Roanoke River and contains both an uplake, riverine section that receives discharges from an upstream dam and a deepwater lentic area in the downstream extent of the reservoir. The reservoir extends from John $\mathrm{H}$. Kerr Dam downstream $54 \mathrm{~km}$ to Lake Gaston Dam. Roanoke Rapids Lake lies immediately downstream of Lake Gaston. Lake Gaston has a mean depth of $6 \mathrm{~m}$ and a maximum depth of $29 \mathrm{~m}$ and is classified as mesotrophic (chlorophyll $a \cong 6.5$ $\mu \mathrm{g} / \mathrm{L})$. Water levels are generally stable $( \pm 0.3 \mathrm{~m})$, with upstream releases from John H. Kerr Reservoir balanced by releases into Roanoke Rapids Lake. Lake Gaston Dam is operated for hydroelectric power generation, flood control, and water-based recreation. John H. Kerr Dam is also operated for hydroelectric generation, and because of hypolimnetic releases from that dam, the upper, riverine section of Lake Gaston receives inputs of cool, low-oxygen water during the months of summer stratification. Lake Gaston supports a popular striped bass fishery, which is maintained by annual stockings by the North Carolina Wildlife Resources Commission.

\section{Methods}

Fish collection and tag implantation.-Adult striped bass (minimum weight $1.35 \mathrm{~kg}$ ) were collected by gill net or electrofishing from December 1996 through May 1997 for implantation of ultrasonic tags programmed with unique frequency and pulse interval combinations (VEMCO, Ltd., Shad Bay, Nova Scotia). Fish were measured for total length $(\mathrm{cm})$, weighed, sexed, and surgically implanted with transmitters following the procedures of Haeseker et al. (1996). During December 1996 and January 1997, 37 fish were collected in gill nets, implanted with transmitters, and released near Lake Gaston Dam. An additional 15 fish were captured in gill nets, implanted, and released into Stonehouse Creek, an embayment $16 \mathrm{~km}$ upstream from Lake Gaston Dam, during February and March 1997. Gill-net collections were conducted at water temperatures ranging from $7^{\circ} \mathrm{C}$ to $10^{\circ} \mathrm{C}$. Nets were set at dusk and checked hourly throughout the night; on all but the final gill-net collection date (6 March, three fish), fish were held overnight in a holding pen measuring $4.5 \times 4.5 \times 2.5 \mathrm{~m}$ fitted with $2.5-\mathrm{cm}$ mesh until there was sufficient light for surgeries. During May 1997, 47 striped bass were captured by pulsed-DC electrofishing, implanted with transmitters, and immediately released below John H. Kerr Dam. Water tempera- 


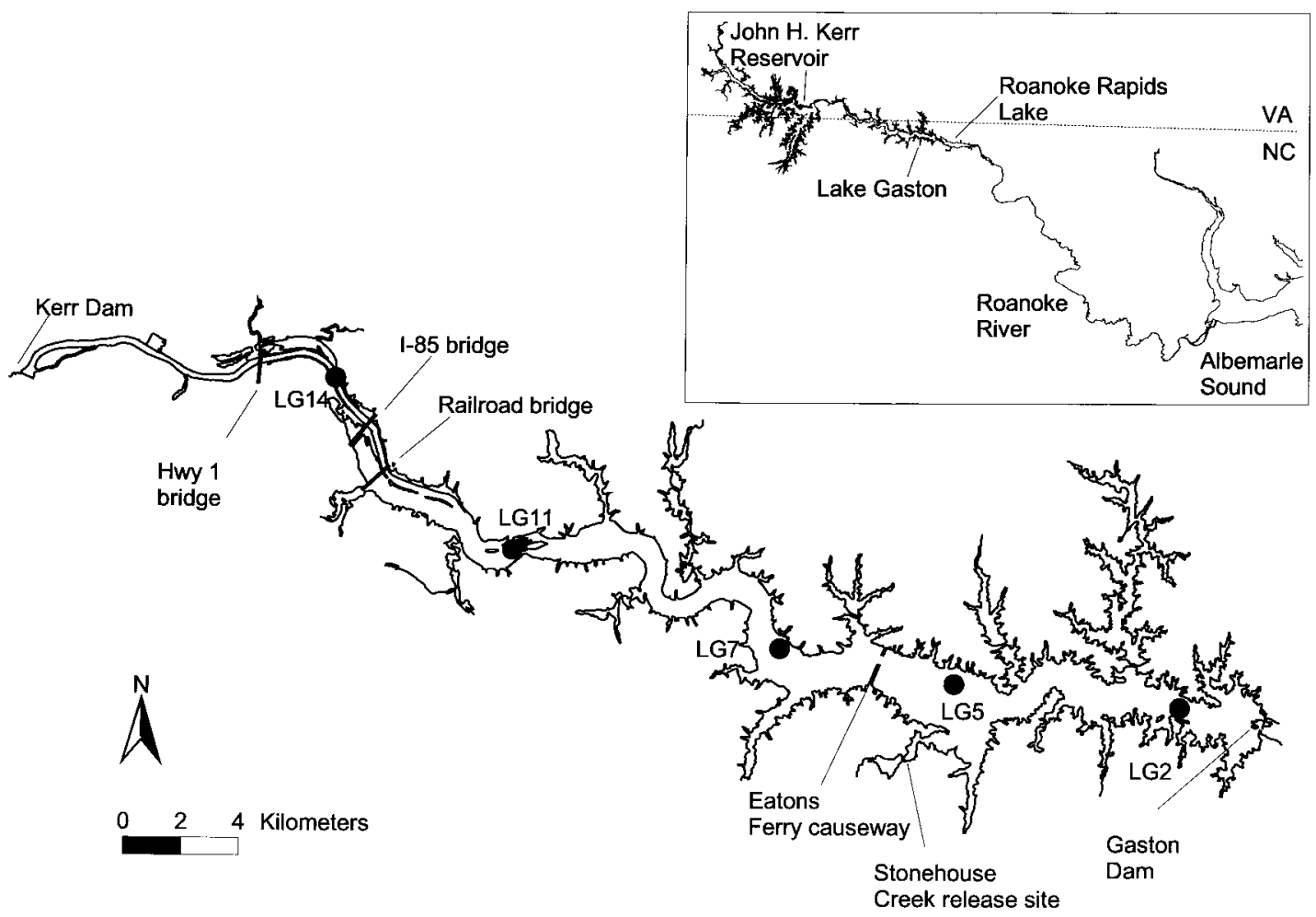

FIgURE 1.-Lake Gaston, Virginia-North Carolina. Sites labeled LG plus a number indicate stations where summer water quality data were collected.

tures during electrofishing collections were around $13^{\circ} \mathrm{C}$, and surgeries were conducted immediately upon capture.

The relative weights (ratio of a fish's weight to the weight of a "standard" fish of the same length) of striped bass implanted with transmitters were calculated using the standard-weight equation proposed by Brown and Murphy (1991). Only fish from winter gill-net collections were used in the calculation of relative weights to avoid possible bias owing to gonadal development in fish captured during the spawning season.

Fish relocation and movement calculations.Transmitters were programmed with a 2-weeks-on, 2-weeks-off duty cycle, resulting in a 2-year battery life. Consequently, searches for tagged fish were conducted every 4 weeks from January 1997 through December 1998. On each search occasion, the entire length of the lake was searched, typically over two consecutive days; we listened for transmitters with a USR-5W ultrasonic receiver and a DH-2 directional hydrophone (Sonotronics, Inc., Tucson, Arizona). Search patterns varied during each search period according to weather, boat traffic, and other factors that affected signal range in an effort to ensure that all transmitters were detected. Fish locations on each search were recorded in Universal Transverse Mercator (UTM) coordinates determined with a global positioning system receiver. The UTM coordinates were entered into a geographical information system database for plotting relocations on a map of the lake and calculating straight-line movement distances.

Movement was defined as the linear distance between monthly relocation points. The movement rate $(\mathrm{m} / \mathrm{month})$ for all fish was calculated beginning with the second relocation in order to exclude behavior that may have been biased by postoperative stress. Not all fish were relocated on every search, and monthly movements were calculated only for fish relocated during consecutive searches. For assessment of seasonal movement rates, data were grouped by season before conducting statistical analyses (winter = January, February, and March; spring = April, May, and June; summer $=$ July, August, and September; fall = October, November, and December).

Because individual fish were repeatedly sampled, we used a repeated-measures split-plot analysis of variance (ANOVA) design for statistical 
analyses of movement in order to separate the variance attributable to individual fish behavior from that owing to our treatment variables (season and sex; Maceina et al. 1994). Because movement data tend not to be normally distributed, we transformed the data by means of the Box-Cox procedure before analysis (Turchin 1998). The transformation was

$$
y=\frac{(x+1)^{0.2}-1}{0.00039527}
$$

where $y$ is the transformed value, and $x$ is the untransformed value (in $\mathrm{m}$ ). We originally included year as a factor in the ANOVA, but because of the lack of a significant year effect in the full model $(F=0.75, P=0.39)$, we pooled data from both years for subsequent analyses.

We tested for seasonal differences in the distribution of striped bass within the reservoir by constructing an $R \times C$ contingency table (Snedecor and Cochran 1980). Fish locations were assigned to one of three areas of the reservoir: the upper lake, which extends from John H. Kerr Dam to the railroad bridge (Figure 1); the middle lake, which extends from the railroad bridge to the Eaton's Ferry causeway; and the lower lake, which extends from the Eaton's Ferry causeway to Lake Gaston Dam. The total number of fish relocations in each area was calculated for each season. We then tested for seasonal differences in the distribution of fish among reservoir areas by means of a chi-square test (Snedecor and Cochran 1980). Additionally, for fish relocated at least 15 times over the course of the study, we used the UTM equivalent of longitude to determine longitudinal position in the lake by season and year to assess the possibility that individual fish exhibited fidelity to specific areas of the lake.

Summer habitat availability.-Oxygen-temperature profiles were collected monthly during both years from June through September at five stations located along the main channel of the lake (Figure 1). Profiles at each station consisted of readings at the surface and at 1-m intervals for the entire water column. Water quality profiles were evaluated to determine the spatial and temporal availability of suitable habitat for adult striped bass during the summer. The criteria used for definition of suitable habitat were temperatures of $26^{\circ} \mathrm{C}$ or less and dissolved oxygen levels of $2 \mathrm{mg} / \mathrm{L}$ or more. Additional oxygentemperature profile data were collected during monthly searches, particularly in the vicinity of John H. Kerr Dam, where hypolimnetic discharges led to temporal variability in tailrace water quality depending on generating schedules.

\section{Results}

Striped bass collected in gill nets exhibited a strong tendency to move downstream through the dam turbines following surgery whether they were released near the dam or $16 \mathrm{~km}$ upstream. Of the 52 fish captured by gill nets and implanted with transmitters, only 12 were relocated in Lake Gaston. Searches in Roanoke Rapids Lake and the Roanoke River resulted in relocation of 28 of the fish captured by gill nets at locations ranging from immediately below Lake Gaston Dam to Albemarle Sound, $234 \mathrm{~km}$ downstream from Lake Gaston (Figure 1). Of the 12 fish from gill-net collections that remained in Lake Gaston, only 5 were confirmed to be alive one month after capture and surgery. Striped bass collected by electrofishing showed a similar tendency to move downstream immediately following release, but none passed through the turbines, and postsurgery survival was also higher, resulting in the survival of 46 of the 47 fish collected by electrofishing for at least 2 months after surgery. Thus, our sample size was 51 fish as of May 1997. The number of fish at large declined throughout the course of the study because of harvest, nonharvest mortality, and turbine passage, with 13 fish remaining alive in Lake Gaston by the end of the study in December 1998 . The relative weights of the striped bass captured in gill nets during the winter of 1996-1997 averaged $87.9(\mathrm{SE}=10.9)$.

Monthly striped bass relocation rates ranged from $46 \%$ to $100 \%$ during the course of the study, with the lowest rates experienced early in the first year. Movement data for at least one pair of consecutive monthly relocations were collected on 42 individual fish; the number of relocations per fish providing movement data ranged from 1 to 20 (Table 1). Altogether, 294 measures of monthly movement by individual fish were collected during the 2 years of the study.

The observed monthly change in location of individual fish ranged from less than $1 \mathrm{~km}$ to $44 \mathrm{~km}$. The average untransformed monthly distance moved across all seasons and years was 7,340 m $(\mathrm{SE}=544 \mathrm{~m})$. No significant differences in distances moved were detected among seasons $(F=$ $0.41, P=0.74)$ or between sexes $(F=0.03, P=$ $0.87)$.

Summer conditions reduced the amount of suitable habitat available for adult striped bass during both years of the study (Figure 2). By July, the 
TABLE 1.-Tagging and relocation data for striped bass implanted with ultrasonic tags in Lake Gaston, VirginiaNorth Carolina, in 1996-1997. Number of relocations refers to the number of times a fish was relocated in consecutive months, which provides monthly movement distances; $\mathrm{M}=$ male, $\mathrm{F}=$ female.

\begin{tabular}{|c|c|c|c|c|c|}
\hline $\begin{array}{c}\text { Tag } \\
\text { num- } \\
\text { ber }\end{array}$ & $\begin{array}{l}\text { Total } \\
\text { length } \\
(\mathrm{cm})\end{array}$ & $\begin{array}{l}\text { Weight } \\
(\mathrm{kg})\end{array}$ & Sex & $\begin{array}{c}\text { Months } \\
\text { at } \\
\text { large }\end{array}$ & $\begin{array}{l}\text { Number } \\
\text { of } \\
\text { reloca- } \\
\text { tions }\end{array}$ \\
\hline 2846 & 57.7 & 1.93 & $\mathrm{M}$ & 24 & 20 \\
\hline 2848 & 62.9 & 3.61 & M & 4 & 3 \\
\hline 2850 & 54.2 & 2.53 & M & 4 & 2 \\
\hline 2851 & 58.2 & 2.24 & $\mathrm{~F}$ & 22 & 20 \\
\hline 2855 & 61.9 & 3.35 & $\mathrm{M}$ & 4 & 2 \\
\hline 2856 & 75.0 & 6.28 & $\mathrm{M}$ & 19 & 10 \\
\hline 2857 & 56.0 & 2.67 & $\mathrm{M}$ & 3 & 1 \\
\hline 2859 & 59.8 & 2.22 & $\mathrm{M}$ & 2 & 1 \\
\hline 3006 & 83.2 & 7.78 & $\mathrm{~F}$ & 19 & 9 \\
\hline 3008 & 81.3 & 7.61 & $\mathrm{M}$ & 4 & 1 \\
\hline 3010 & 73.3 & 5.88 & $\mathrm{~F}$ & 4 & 3 \\
\hline 3016 & 56.9 & 2.67 & $\mathrm{M}$ & 18 & 13 \\
\hline 3018 & 72.1 & 4.66 & $\mathrm{~F}$ & 11 & 6 \\
\hline 3021 & 61.4 & 3.13 & M & 17 & 8 \\
\hline 3023 & 56.9 & 2.84 & M & 5 & 1 \\
\hline 3026 & 59.2 & 2.70 & $\mathrm{~F}$ & 7 & 7 \\
\hline 3028 & 63.3 & 3.30 & $\mathrm{~F}$ & 4 & 2 \\
\hline 3029 & 65.8 & 3.58 & $\mathrm{~F}$ & 4 & 1 \\
\hline 3030 & 67.0 & 4.18 & $\mathrm{~F}$ & 4 & 2 \\
\hline 3034 & 90.8 & 11.0 & $\mathrm{~F}$ & 19 & 15 \\
\hline 3037 & 58.3 & 2.61 & M & 4 & 4 \\
\hline 3043 & 57.1 & 2.36 & $\mathrm{M}$ & 8 & 6 \\
\hline 3044 & 53.2 & 2.22 & $\mathrm{M}$ & 4 & 3 \\
\hline 3048 & 63.7 & 4.09 & $\mathrm{M}$ & 14 & 5 \\
\hline 3050 & 62.0 & 3.24 & $\mathrm{M}$ & 4 & 1 \\
\hline 3052 & 82.8 & 7.64 & $\mathrm{M}$ & 19 & 13 \\
\hline 3055 & 64.8 & 3.78 & $\mathrm{M}$ & 4 & 2 \\
\hline 3057 & 59.5 & 2.10 & M & 24 & 19 \\
\hline 3058 & 70.0 & 4.03 & $\mathrm{~F}$ & 21 & 20 \\
\hline 3060 & 58.9 & 2.90 & M & 19 & 11 \\
\hline 3061 & 77.7 & 7.13 & $\mathrm{M}$ & 4 & 1 \\
\hline 3064 & 76.9 & 6.31 & M & 5 & 4 \\
\hline 3067 & 65.2 & 9.55 & $\mathrm{M}$ & 19 & 15 \\
\hline 3069 & 60.0 & 3.18 & M & 4 & 2 \\
\hline 3070 & 83.2 & 7.84 & $\mathrm{M}$ & 19 & 13 \\
\hline 3071 & 61.3 & 2.73 & $\mathrm{~F}$ & 13 & 9 \\
\hline 3073 & 67.4 & 4.15 & $\mathrm{~F}$ & 19 & 12 \\
\hline 3074 & 60.2 & 3.15 & $\mathrm{M}$ & 7 & 4 \\
\hline 3077 & 56.1 & 2.24 & $\mathrm{M}$ & 19 & 15 \\
\hline 3082 & 66.8 & 4.09 & M & 6 & 2 \\
\hline 3083 & 59.7 & 3.01 & $\mathrm{M}$ & 7 & 4 \\
\hline 3084 & 60.9 & 3.21 & $\mathrm{M}$ & 5 & 2 \\
\hline
\end{tabular}

proportion of the water column that provided water temperatures of $26^{\circ} \mathrm{C}$ or less and dissolved oxygen concentrations of $2 \mathrm{mg} / \mathrm{L}$ or more began to decline, particularly in downlake areas. There was further restriction of habitat in August, particularly in 1998, when suitable temperature and oxygen conditions were observed only in the uplake area influenced by releases from John H. Kerr Dam. Despite the decline in suitable habitat during the summer months, striped bass were relocated through- out the main channel of the lake during all seasons (Figure 3). Fish tended to be relocated most often in the upper, riverine section of the lake or in downstream basins, with only $22 \%$ of 435 relocations occurring in the middle section of the reservoir. The distribution of relocated fish among the upper, middle, and lower sections of the lake did differ significantly among seasons $\left(\chi^{2}=55.34, P\right.$ $<0.001$ ), with the greatest deviations being higher numbers of fish in the upper lake during spring and in the lower lake during winter. Similarly, over the two summers of the study, striped bass were observed in most areas of the lake, although again there was a tendency for fish to use areas nearer one of the dams rather than the midlake areas (Figure 4). Several fish remained in the area of the John H. Kerr Reservoir tailrace throughout the summer, but they would drop downstream when discharges reduced the dissolved oxygen level to nearly $0 \mathrm{mg} / \mathrm{L}$.

The striped bass that we relocated consistently over the study tended to exhibit fidelity to specific areas of the reservoir throughout all seasons and both years, except during spring spawning runs (Figure 5). Some fish (e.g., 3057 and 3077) were repeatedly relocated near Lake Gaston Dam, while others (e.g., 2851 and 3058) occupied the large basin below Eaton's Ferry further uplake, and one (3034) remained near John H. Kerr Dam throughout the study. Only one of the fish that was at large throughout the study (3052) exhibited behavior not suggestive of fidelity to a specific reservoir area.

\section{Discussion}

Telemetry-based movement data collected on 42 adult striped bass over 2 years in Lake Gaston did not reveal significant $(P=0.74)$ seasonal differences in movement rates. This finding differs from earlier reports addressing seasonal movement patterns. Striped bass in an Oklahoma reservoir were observed by Wilkerson and Fisher (1997) to move greater distances in spring than in summer. Similarly, Cheek et al. (1985) reported substantially higher movement rates in spring and winter than in summer and fall. Higher spring movement rates were also documented for reservoir striped bass by Braschler et al. (1989). The differences between our findings and those of earlier workers are probably attributable to our monthly relocation schedule. Earlier studies calculated movements on the basis of more frequent relocations and reported them in terms of kilometers per day (Cheek et al. 1985; Braschler et al. 1989; Wilkerson and Fisher 1997). It is likely that daily relocations would de- 
1997

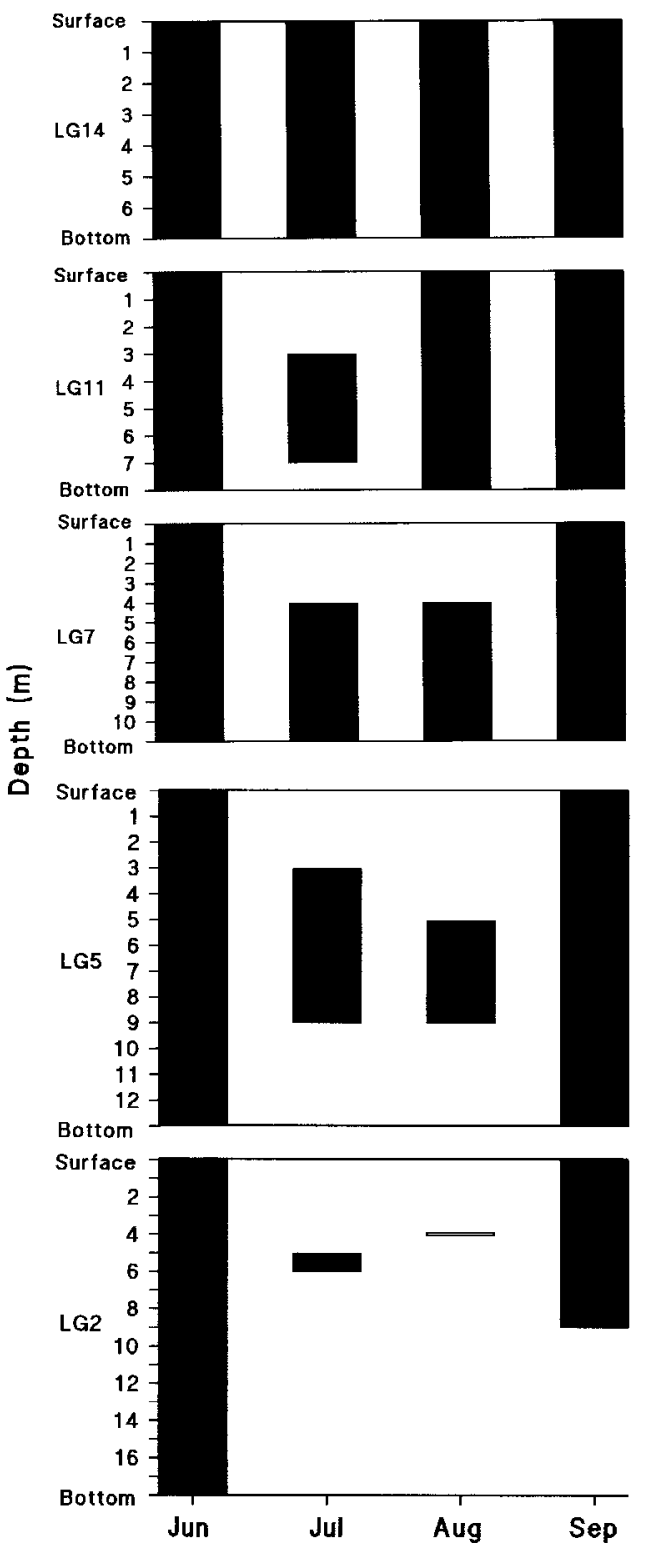

1998
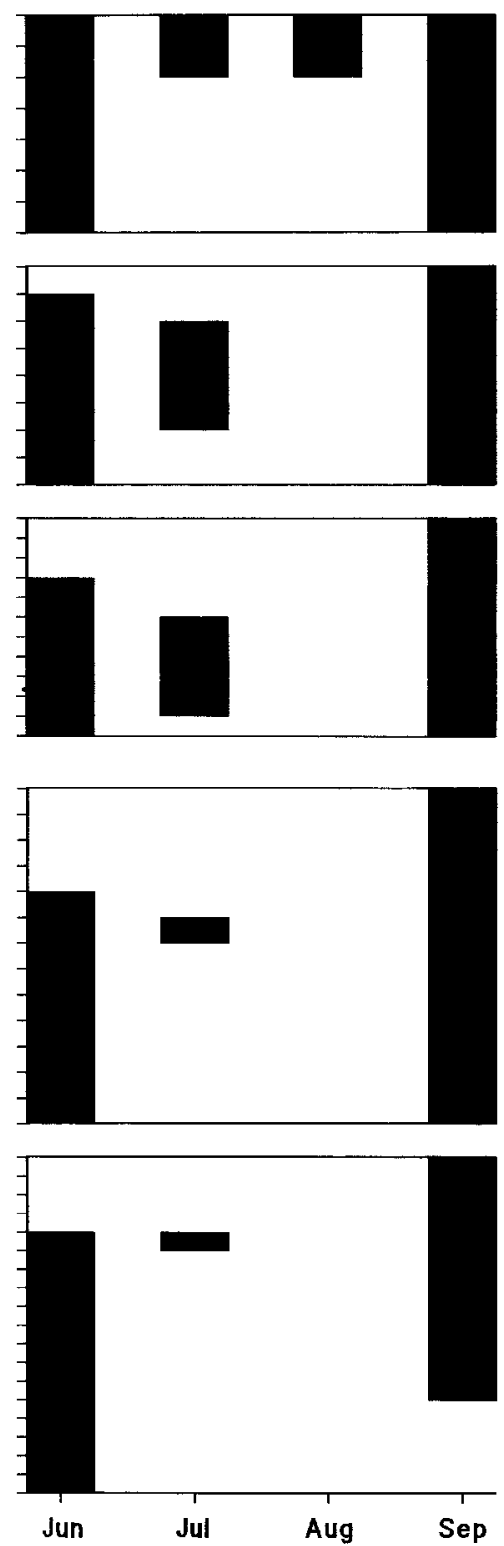

Figure 2.-Availability of suitable summer habitat for adult striped bass in Lake Gaston, Virginia-North Carolina, in 1997 and 1998. Shaded areas indicate portions of the water column where temperatures were $26^{\circ} \mathrm{C}$ or less and dissolved oxygen levels were $2 \mathrm{mg} / \mathrm{L}$ or more.

tect differences in seasonal activity levels that our monthly relocations masked. Our data suggest that on a longer temporal scale, striped bass remain within comparably sized ranges in all seasons despite any differences in seasonal activity levels that may exist.

Wilkerson and Fisher (1997) reported fidelity by striped bass to a specific tributary of an Oklahoma reservoir and related their findings to habitat conditions. Similarly, Cheek et al. (1985) noted that the striped bass in two tributaries of a Tennessee reservoir were most often relocated within the tributary where they were originally captured, and these researchers interpreted this as being related 

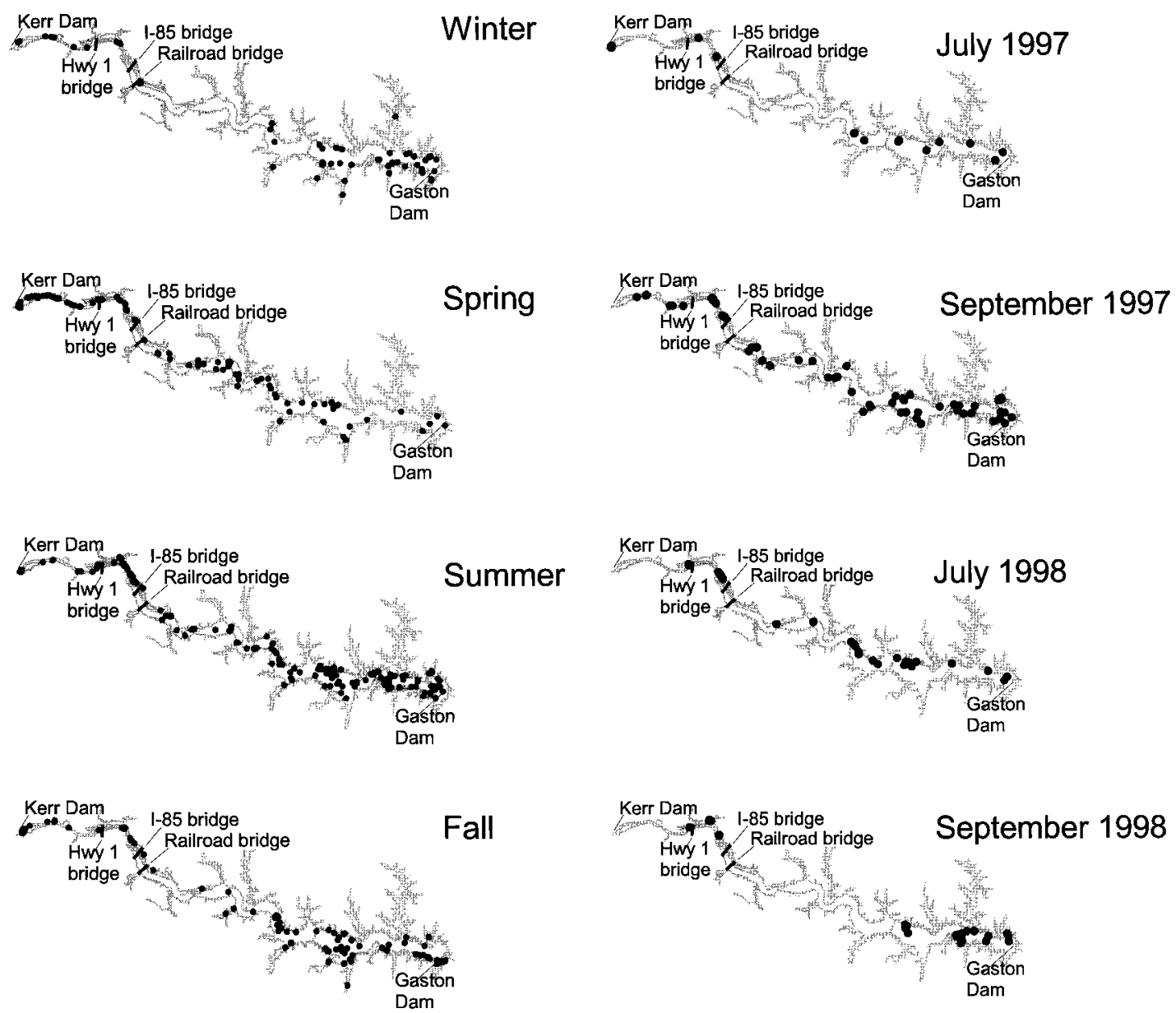

Figure 3.- Seasonal locations of adult striped bass in Lake Gaston, Virginia-North Carolina, in 1997 1998. Points represent all fish relocations in both years and include multiple relocations for individual fish.

to the availability of suitable summer habitat. Our study supports the earlier findings that individual striped bass exhibit fidelity to specific tributaries or reservoir basins, but this fidelity cannot be as easily related to observed spatial differences in habitat availability. We observed distinct home ranges for individual striped bass throughout Lake Gaston, and except for spring spawning runs, these ranges were maintained year-round, including summer months when spatial differences in habitat quality were evident.

The differences between our results and those of earlier studies may be related to time of tagging. Wilkerson and Fisher (1997) collected and tagged fish from winter through early spring, while Cheek et al. (1985) tagged fish from late summer through early winter. If individual striped bass tend to oc-

FIGURE 4.- Summer locations of adult striped bass in Lake Gaston, Virginia-North Carolina, in 1997-1998. Points represent all fish relocations in both years and include multiple relocations for individual fish.

cupy specific areas of reservoirs, both of these studies may have involved the collection of fish that were already within their nonspawning home ranges. Most of the fish in our study were collected in the tailrace of an upstream dam during the spawning season, which may have resulted in a more random sample of the lake population. Following the spawning season, our fish redispersed to individual home ranges, which were dispersed throughout the lake. Support for this conclusion comes from three fish in our study that were captured by winter gill netting. Two of these fish were captured near Lake Gaston Dam and were consistently relocated in the basin associated with the dam. A third fish captured by gill netting was originally collected in Stonehouse Creek, an embayment $16 \mathrm{~km}$ upstream from Lake Gaston Dam, and 
exhibited a similar tendency to stay within a large basin adjacent to the embayment for the remainder of the study.

Striped bass in Lake Gaston were widely dispersed throughout the lake during all seasons. Earlier studies of the distribution of striped bass in southern U.S. reservoirs have generally reported more aggregation in areas of suitable habitat in summer than in seasons when habitat was not spatially limited (Combs and Peltz 1982; Farquhar and Gutreuter 1989). Cheek et al. (1985) reported that striped bass in a Tennessee reservoir avoided waters warmer than $25^{\circ} \mathrm{C}$, resulting in summer aggregations in the tailwaters of upstream dams. Similarly, Moss (1985) observed summer aggregations of striped bass in the tailwaters of Alabama reservoirs after water temperatures reached $27^{\circ} \mathrm{C}$ in the main part of the lake. Tagged striped bass in Lake Gaston were not conspicuously aggregated during the summer months and did not exhibit a tendency to migrate from their usual activity ranges in search of different summer habitat, despite evidence that suitable habitat in downlake areas was limited or absent during at least one month each summer. Zale et al. (1990) and Van Horn et al. (1998) reported that striped bass can tolerate water temperatures between $27^{\circ} \mathrm{C}$ and $28^{\circ} \mathrm{C}$ for up to a month, and our findings support the conclusion that striped bass will occupy waters at these temperatures. It is likely that the striped bass occupying downlake home ranges in Lake Gaston were exposed to water temperatures between $27^{\circ} \mathrm{C}$ and $28^{\circ} \mathrm{C}$ or to a dissolved oxygen level of less than $2 \mathrm{mg} / \mathrm{L}$ during the hottest weeks of the summer, but not for longer than a month in either year of our study.

Despite the use of suboptimal summer habitats by a large percentage of our tagged fish, there was no evidence that the Lake Gaston striped bass population suffers unusually high mortality rates. Estimated seasonal instantaneous rates of natural mortality that were based on a modified version of the capture-recapture model developed by Pollock et al. (1995) indicate that the natural mortality of striped bass in Lake Gaston is concentrated in the summer months, but results in an annual rate of only 0.11 (Hightower and Jackson 2000). This estimate is similar to the rate assumed in coastal population models (Cohen et al. 1983; Hightower and Jackson 2000).

There is evidence that the striped bass in Lake Gaston are in poorer condition than are many other reservoir populations. The relative weights of striped bass in Lake Gaston in winter were below the 50th percentile reported by Brown and Murphy (1991) for inland striped bass populations. Haeseker et al. (1996) reported that the relative weights of striped bass in Albemarle Sound in winter reflected an increase from the lower levels observed during the summer months. If the winter relative weights that we observed reflect a similar increase, then the summer relative weights of striped bass in Lake Gaston may be near the low end of the range previously reported for this species in reservoirs. Our data do not allow determination of whether the low relative weights that we observed resulted directly from the striped bass's occupation of marginal habitats or from summer habitat segregation from their prey base (Coutant 1985).

Our experience with the capture and release of tagged striped bass suggests some important considerations for future striped bass telemetry studies in reservoirs where turbine passage is possible. Carmichael et al. (1998) reported that striped bass in the Roanoke River that were surgically implanted with tags exhibited strong downriver flight responses following release. Our results confirm the tendency for tagged striped bass to move downstream following handling and release. Of 52 striped bass collected in gill nets and tagged in the lower $16 \mathrm{~km}$ of Lake Gaston, only 12 were subsequently relocated in the lake. Detection of 28 of the remaining fish in areas below Lake Gaston Dam supports the hypothesis that the majority of our gill-netted fish moved downstream through the turbines. Within $2 \mathrm{~d}$ of release, striped bass collected by electrofishing and tagged at the upper end of Lake Gaston were relocated as much as 32 $\mathrm{km}$ downlake, but none were detected near the dam, and all 47 fish captured by electrofishing remained in the lake for at least 1 month. The downstream flight responses following handling that we observed in our study might explain some results from earlier studies. Cheek et al. (1985) collected striped bass from two tributaries and the main basin of Watts Bar Reservoir in Tennessee, where the dam is operated for hydropower. They reported that few of the fish captured with nets and released in the main basin were ever relocated, while most of the fish captured by electrofishing in tributary arms further from the dam were successfully relocated on subsequent searches. Similarly, Wilkerson and Fisher (1997) captured striped bass for tag implantation using both gill nets and electrofishing in Robert S. Kerr Reservoir, which also has a hydropower facility at the dam. All 12 of the fish that they collected by electrofishing were re- 

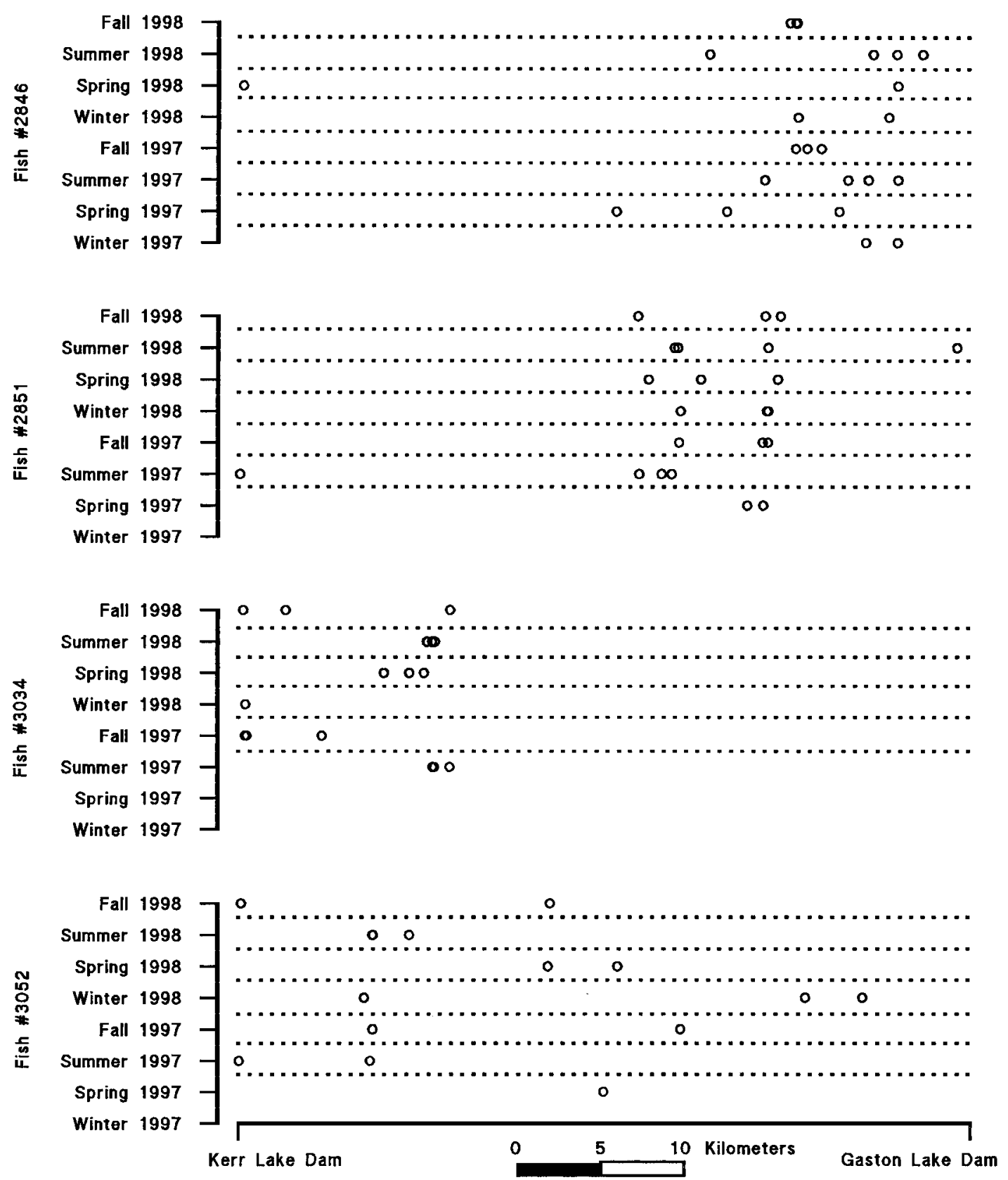

FIGURE 5.-Distribution of individual striped bass relocations in Lake Gaston, Virginia - North Carolina, in 19971998.

located within the lake, but 7 out of the 10 fish collected in gill nets were never relocated, and they report that at least 1 fish was located in the dam tailwaters. We also observed higher postoperative mortality among fish captured in gill nets that remained in Lake Gaston than among those collected by electrofishing. Our experiences, combined with those from earlier studies, thus suggest that telemetry studies with striped bass in hydropower reservoirs should be designed to facilitate release of fish as far from the dam as practicable and that the use of nets should be avoided.

Our study documents that striped bass in Lake Gaston occupy relatively limited home ranges 


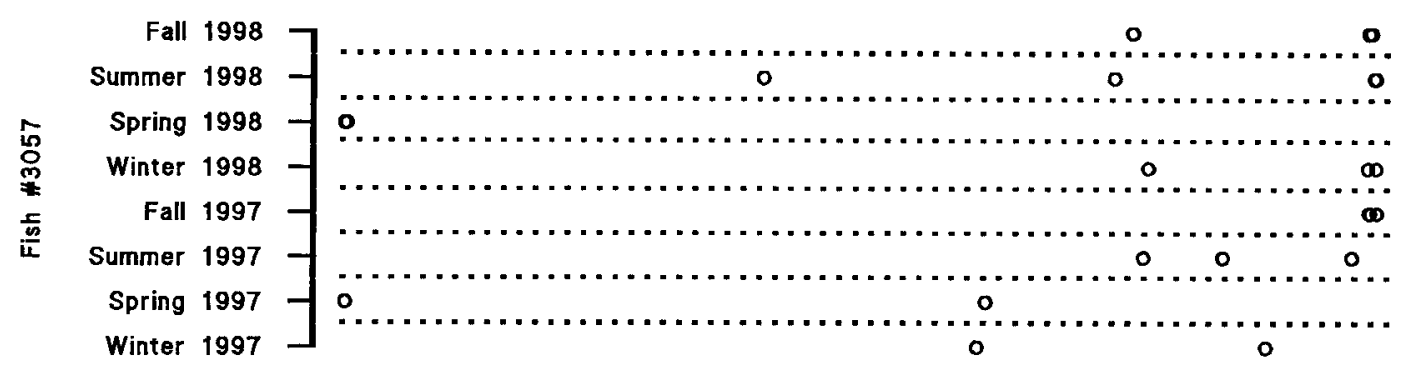
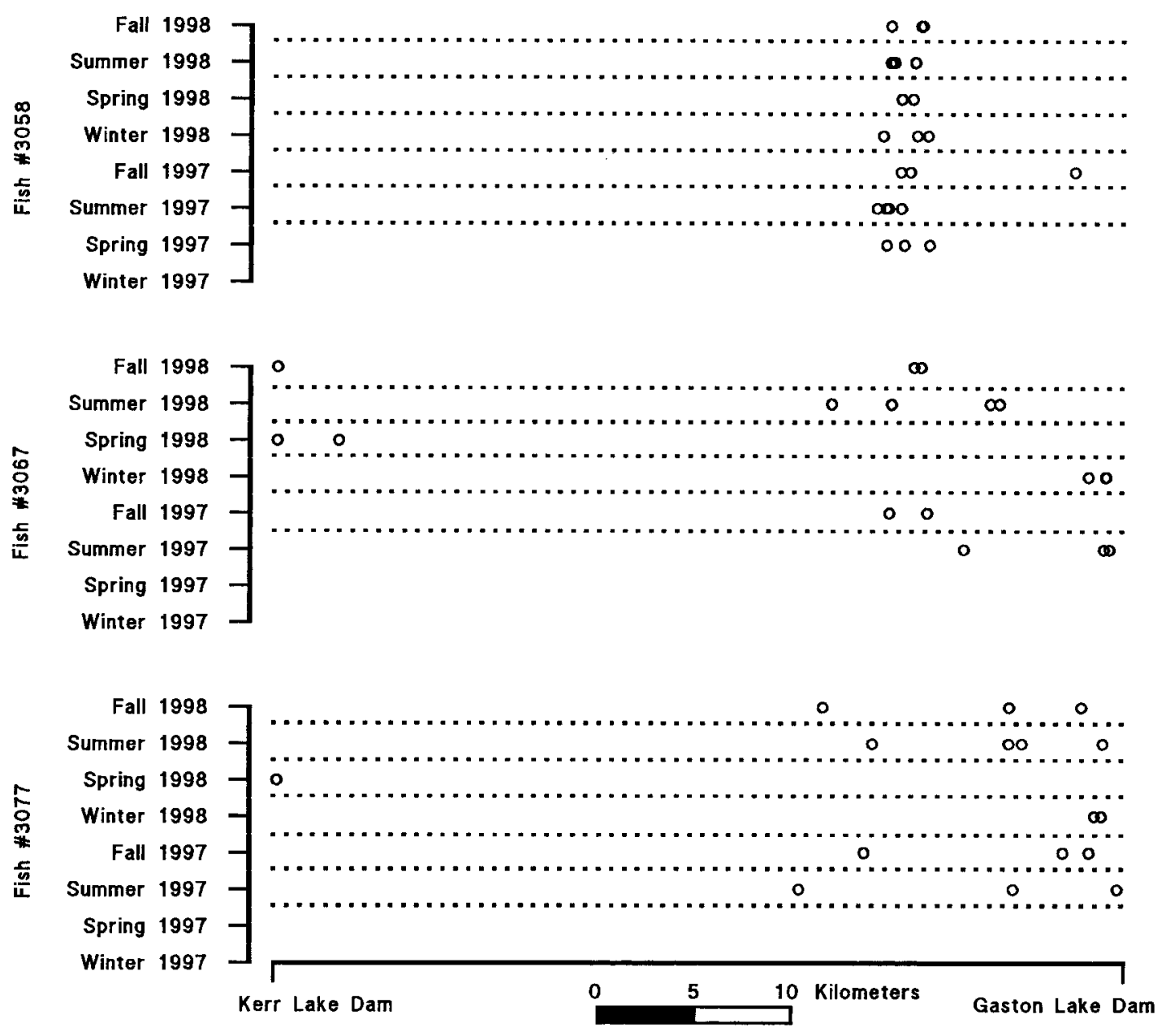

FIGURE 5.-Continued.

throughout most of the year despite spatial differences in the availability of summer habitat. These results indicate that more spatially explicit management strategies may be appropriate for reservoir striped bass populations. Van Den Avyle and Higginbotham (1980) reported that striped bass fingerlings stocked into Watts Bar Reservoir tend- ed to remain within the general area in which they were stocked. If dispersal of stocked fingerlings is limited and adult home ranges are ultimately established near stocking areas, then stocking programs should be designed to distribute fish throughout the suitable habitats in a reservoir to minimize the chance that high-density and low- 
density areas will be created. Similarly, if the tendency of striped bass to occupy particular home ranges precludes large-scale mixing and redistribution, angling pressure might also be expected to influence smaller spatial scales than the whole reservoir. Such effects might be ameliorated by adjusting local stocking rates in accordance with spatial variations in fishing pressure.

\section{Acknowledgments}

Collection of fish for tag implantation was facilitated through the efforts of B. Collart, W. Jones, and S. Van Horn of the North Carolina Wildlife Resources Commission. Tracking was conducted with the assistance of numerous students from the Department of Zoology at North Carolina State University. Water quality data were provided by R. Graham of Virginia Power. Funding was provided by the North Carolina Wildlife Resources Commission through Federal Aid in Sport Fish Restoration project F-30 and by Virginia Power. K. Pollock provided valuable advice on the design of statistical analyses; P. Bettoli, R. Graham, J. Kornegay, D. Michaelson, K. Nelson, S. Van Horn and two anonymous reviewers provided valuable comments on earlier drafts of the manuscript. The North Carolina Cooperative Fish and Wildlife Research Unit is a cooperative program of the Biological Resources Division, U.S. Geological Survey; the North Carolina Wildlife Resources Commission; and North Carolina State University.

\section{References}

Axon, J. R., and D. K. Whitehurst. 1985. Striped bass management in lakes with emphasis on management problems. Transactions of the American Fisheries Society 114:8-11.

Bailey, W. M. 1975. An evaluation of striped bass introduction in the southeastern United States. Proceedings of the Annual Conference Southeastern Association of Game and Fish Commissioners 28(1974):54-68.

Braschler, D. W., M. G. White, and J. W. Foltz. 1989. Movements and habitat selection of striped bass in the Santee-Cooper Reservoir. Proceedings of the Annual Conference Southeastern Association of Fish and Wildlife Agencies 42(1988):27-34.

Brown, M. L., and B. R. Murphy. 1991. Standard weights $\left(W_{s}\right)$ for striped bass, white bass, and hybrid striped bass. North American Journal of Fisheries Management 11:451-467

Carmichael, J. T., S. L. Haeseker, and J. E. Hightower. 1998. Spawning migration of telemetered striped bass in the Roanoke River, North Carolina. Transactions of the American Fisheries Society 127:286-297.

Cheek, T. E., M. J. Van Den Avyle, and C. C. Coutant. 1985. Influences of water quality on distribution of striped bass in a Tennessee impoundment. Transactions of the American Fisheries Society 114:6776.

Cohen, J. E., S. W. Christensen, and C. P. Goodyear. 1983. A stochastic age-structured population model of striped bass (Morone saxatilis) in the Potomac River. Canadian Journal of Fisheries and Aquatic Sciences 40:2170-2183.

Combs, D. L., and L. R. Peltz. 1982. Seasonal distribution of striped bass in Keystone Reservoir, Oklahoma. North American Journal of Fisheries Management 2:66-73.

Coutant, C. C. 1985. Striped bass, temperature, and dissolved oxygen: a speculative hypothesis for environmental risk. Transactions of the American Fisheries Society 114:31-61.

Farquhar, B. W., and S. Gutreuter. 1989. Distribution and migration of adult striped bass in Lake Whitney, Texas. Transactions of the American Fisheries Society 118:523-532.

Haeseker, S. L., J. T. Carmichael, and J. E. Hightower. 1996. Summer distribution and condition of striped bass within Albemarle Sound, North Carolina. Transactions of the American Fisheries Society 125: 690-704.

Hightower, J. E., and J. R. Jackson. 2000. Distribution and natural mortality of stocked striped bass in Lake Gaston, North Carolina. North Carolina Wildlife Resources Commission, Federal Aid in Sport Fish Restoration project F-30, Study 5, Final Report, Raleigh.

Kohler, C. C., J. J. Ney, and W. E. Kelso. 1986. Filling the void: development of a pelagic fishery and its consequences to littoral fishes in a Virginia mainstream reservoir. Pages 166-177 in G. E. Hall and M. J. Van Den Avyle, editors. Reservoir fisheries management: strategies for the '80s. American Fisheries Society, Southern Division, Reservoir Committee, Bethesda, Maryland.

Maceina, M. J., P. W. Bettoli, and D. R. DeVries. 1994. Use of a split-plot analysis of variance design for repeated-measures fishery data. Fisheries 19(3):1420.

Matthews, W. J. 1985. Summer mortality of striped bass in reservoirs of the United States. Transactions of the American Fisheries Society 114:62-66.

Moss, J. L. 1985. Summer selection of thermal refuges by striped bass in Alabama reservoirs and tailwaters. Transactions of the American Fisheries Society 114:77-83.

Nash, V. S., W. E. Hayes, R. L. Self, and J. P. Kirk. 1988. Effect of striped bass introduction in Lake Wateree, South Carolina. Proceedings of the Annual Conference Southeastern Association of Fish and Wildlife Agencies 41(1987):48-54.

Pollock, K. H., C. M. Bunck, S. R. Winterstein, and C.L. Chen. 1995. A capture-recapture survival analysis model for radio-tagged animals. Journal of Applied Statistics 22:661-672.

Snedecor, G. W., and W. G. Cochran. 1980. Statistical methods, 7th edition. Iowa State University Press, Ames. 
Stevens, R. E. 1958. The striped bass of the Santee-Cooper reservoir. Proceedings of the Annual Conference Southeastern Association of Game and Fish Commissioners 11(1957):253-264.

Turchin, P. 1998. Quantitative analysis of movement: measuring and modeling population redistribution in animals and plants. Sinauer Associates, Sunderland, Massachusetts.

Van Den Avyle, M. J., and B. J. Higginbotham. 1980. Growth, survival, and distribution of striped bass stocked into Watts Bar Reservoir, Tennessee. Proceedings of the Annual Conference Southeastern Association of Fish and Wildlife Agencies 33(1979):361-370.
Van Horn, S. L., J. R. Finke, and D. Degan. 1998. Summer habitat selection of striped bass in Lake Norman. Proceedings of the Annual Conference Southeastern Association of Fish and Wildlife Agencies 50(1996):91-97.

Wilkerson, M. L., and W. L. Fisher. 1997. Striped bass distribution, movements, and site fidelity in Robert S. Kerr Reservoir, Oklahoma. North American Journal of Fisheries Management 17:677-686.

Zale, A. V., A. D. Wiechman, R. L. Lochmiller, and J. Burroughs. 1990. Limnological conditions associated with summer mortality of striped bass in Keystone Reservoir, Oklahoma. Transactions of the American Fisheries Society 119:72-76. 